\title{
DEVELOPING OF HADANG TRADITIONAL GAME THROUGH PLYOMETRIC TRAINING ON FIFTH GRADE STUDENTS OF SD NEGERI 98 NORTH BENGKULU
}

${ }^{1}$ Supriyanto, ${ }^{2}$ Martiani

Correspondence: Dehasen University of Bengkulu, Bengkulu, Indonesia E-mail: supriyanto@unived.ac.id

\section{Abstrak}

Metode yang digunakan dalam penelitian ini yaitu research-based development $(R \& D)$, bertujuan untuk mengembangkan produk latihan plyometric. Sampel penelitian yaitu Siswa kelas V SD Negeri 98 Bengkulu Utara yang berjumlah 28 orang. Berdasarkan hasil penelitian menggunakan metode plyometric menunjukkan bahwa kondisi fisik dasar siswa kelas V SD Negeri 98 Bengkulu Utara dalam katagori baik. Hal ini dibuktikan dengan hasil tes kognitif dan psikomotor yang telah dilakukan pada uji coba kelompok kecil dengan perolehan presentase $20 \%$ (2 orang) dengan kategori sangat baik, presentase $50 \%$ (5 orang) dengan kategori baik, presentase $10 \%$ (1 orang) dengan kategori cukup dan presentase $20 \%$ (2 orang) dengan katagori kurang. Sedangkan pada uji coba kelompok besar diperoleh presentase $21 \%$ (6 orang) dengan kategori sangat baik, presentase $43 \%$ (12 orang) dengan kategori baik, presentase $25 \%$ (7 orang) dengan kategori cukup, dan presentase 11\% (3 orang) dengan kategori kurang. Disimpulkan bahwa metode plyometric layak digunakan untuk siswa kelas V SD Negeri 98 Bengkulu Utara.

Kata Kunci: Permainan Tradisional Hadang, Metode Plyometric

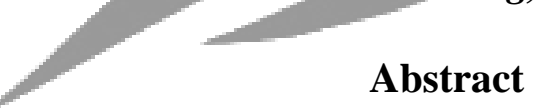

The method was research-based development (R\&D), which aimed to develop plyometric utraining $\backslash$ products. EThe- sample of this $\backslash$ research wase thei fifth grade students of SD Negeri 98 North Bengkulu, totaling 28 people. Based on the results of research using the plyometric method showed that the basic physical conditions of fifth grade students at SD Negeri 98 Bengkulu Utara in good categories. This was proven by the results of cognitive and psychomotor tests which were conducted in small group trials with the acquisition of a percentage of $20 \%$ ( 2 people) with very good categories, the percentage of $50 \%$ (5 people) with good categories, the percentage of $10 \%$ ( 1 person) with enough categories and the percentage of $20 \%$ ( 2 people) with less categories. Whereas in the large group trial the percentage was obtained $21 \%$ (6 people) with very good category, the percentage of $43 \%$ (12 people) with good category, the percentage of $25 \%$ ( 7 people) with enough categories, and the percentage of $11 \%$ (3 people) with less category. It was concluded that the plyometric method was suitable for use in fifth grade students at SD Negeri 98 North Bengkulu.

\section{Keywords: Hadang Traditional Game, Plyometric Method}

PJKR

http://jurnal.unimed.ac.id/2012/index.php/jpehr 


\section{Introduction}

Games are one form of activity in Physical Education lessons in Primary Schools. Playing is a necessity of every individual and exists as a natural instinct which is present from birth. Children will play with pleasure and burden. Natural instincts must be nurtured and channeled to positive things in a good and controlled way.

Traditional games are a means to introduce children to the cultural values and social norms needed to establish social relations or contacts and play a role in accordance with social position in society. Traditional games don't just provide recreational or fun value. Sabaruddin Yunis B (2014) "Recreation is usually done when a person has spare time, when he/she is free from work or duties, after the day-to-day needs are met". Recreation is usually done when you have free time, free from work or tasks, after your daily needs are met.

More than that, traditional games also have physical education values (sports) and even social values. That is because in traditional games there are elements such as sportsmanship, honesty, accuracy, agility, accuracy in determining steps, and working together in groups.

Hadang game is a kind of regional game from Indonesia which we can still find currently being played by primary school children. This game is a group game consisting of two groups, where each team consists of 5-7 people. The point of the game is to block the opponent from being able to pass through the line to the last line back and forth, and to win all the group members must complete the process of going back and forth in a designated area.

Each region has a game that the implementation is almost the same or a lot of similarities with games in other regions. About the name of the game there are the same, but not infrequently the name is different from other regions. As an example, it can be stated that in Central Java it is known as the sodor gobak game, in Jakarta it is called galasin, while in North Sumatra it is called margalah. But clearly the game has the same game rules. In order not to confuse one of the regional names, the Director of Sports gave the name of the game to be hadang game. The name itself is based on observations that in this game the task of the game is to block.

The Researchers conducted the observations and interviews with Physical Education teachers in State Primary School 98 North Bengkulu on August 2, 2018. In learning, Physical Education teachers only provided material in accordance with the existing curriculum without adjusting the environmental conditions in schools. The teacher never gave a hadang game through plyometric training, there was an opportunity to develop a hadang learning model because it had a field and a learning tool for physical education available at school.

After the researchers made observations at SD Negeri 98 North Bengkulu, the researchers wanted to develop traditional games through plyometric exercises to make them more varied so that students were more enthusiastic in learning physical education. Plyometric exercises show the full strength characteristics of muscle contractions with very fast responses, dynamic loading (dynamic loading)

PJKR

http://jurnal.unimed.ac.id/2012/index.php/jpehr 
or very complicated muscle stretching, Radcliffe and Farentinos (1985). Chu (2000) plyometric has the advantage, utilizing the force and speed achieved by accelerating body weight against gravity which this causes the force of speed in training.

The development of hadang games through plyometric training can be used in outdoor or indoor fields. The dominant physical elements that appear in the game include speed of reaction, sprint speed, and agility. Beside these physical elements, there are also other elements, namely the cooperative element which includes teamwork. The development of hadang games in Physical Education learning through plyometric exercises is conducted with the aim of preparing students to move actively in learning. The learning model used was learning motion in a game of running techniques, trickery and concentration. The learning method used was the approach (PAKEM) which is active, innovative, creative, and fun learning. Based on these descriptions, the authors are interested in conducting a study entitled: "Plyometric Training Methods as The Development of Traditional Hadang Games"

Traditional games are physical activities that are carried out consciously and intentionally and use rules based on habits that have traditionally occurred in a community, Sumardiyanto (2010). Traditional Games are the games played by children in ancient times. Most of these games are conducted in groups. Community life in the past which is usually said to not know the outside world has directed and led them to social activities and high togetherness.

Moreover, Indonesian culture in general upholds the values of togetherness. This then encourages the creation of traditional types of games. Unfortunately by the times, especially the rapid development of technology makes this type of game slowly begin to disappear.

Traditional games are a form of game activity that develops from a certain community habit. Boy Indrayana (2017) Traditional games are games that have meaning with noble values and norms which are useful for children to understand and seek balance in the fabric of life- In subsequent developments traditional games are often used as a type of game that has original regional characteristics and adapted to local cultural traditions. In the implementation of traditional games can incorporate elements of folk play and children's play into it. It may even be possible to include activities that contain elements of art such as what is commonly referred to as traditional art, Agustin (2013).

The traditional game here can be synonymous with the term traditional sports. So that an activity can be categorized as a traditional game, of course it must be identified elements of tradition that are closely related to the habits or customs of a particular community group. Besides, the activity must also be strong and contain physical elements that obviously involve large muscle groups and also contain elements which underlie the purpose and objectives of the activity. That is, an activity is said to be a traditional game if the activity is still recognized as having certain traditional characteristics. Involving large muscles 
and the presence of a strategy and its base don't really look like what it shows, Agustin (2013).

Plyometric comes from the word "plyethyein" (Greek) which means to increase, or can also be interpreted from the words "plio" and "metric" which means more and measure, respectively which means stretching, Radcliffe and Farentinos (1985). Plyometric is a method for developing explosive power, which is an important component in achieving plyometric exercises that will produce isometric muscle movements and cause stretch reflexes in the muscles. Plyometric exercises are carried out a series of power exercises specifically designed to help muscles reach their maximum potential levels in the shortest possible time.

Plyometrics is the right exercise for people who are conditioned and are devoted to being athletes in increasing and developing maximum jumps, speed, and strength. Chu (1992) explained that plyometric is an exercise method that emphasizes high-speed movements, plyometric training to apply speed to strength.

\section{Method}

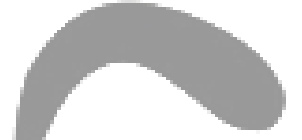

Research and development is usually called research-based development is a type of research that is being increasingly used in solving practical problems in the world of research, especially education and learning research. Borg \& Gall as quoted by Wasis D (2004) research and development is a process used to develop or validate products used in teaching and learning. It was further stated that the research and development procedure basically consisted of two main objectives, namely: (1) Developing the product, and (2) testing the effectiveness of the product in achieving its objectives.

The sample is a part or a representative of the population under study, Arikunto (2010). Sugiyono (2010) sample is a part of the number and characteristics possessed by the population. The sample in this study was the fifth grade students of SD Negeri 98 North Bengkulu, totaling 28 people. The sampling technique in this study was by including all individuals or members of the population into the sample. So the sampling technique in this study was total sampling.

Based on the results of the needs analysis, the next step was the development of a modified Hadang game training model in the form of developing plyometric training models (Drill Scissor Jump, Stride Jumps, Lateral Bound Drill). In developing the training model developed by the researchers made an exercise model based on a study which was then evaluated by one physical education teacher as a learning expert.

The research design was the Plyometric Exercise Model (Drill Scissor Jump, Stride Jumps, Lateral Bound Drill) with the form of development of a game of obstacle to train physical conditions that were suited to the needs of students in learning in order to solve problems in learning so that learning can run more effective and efficient. This training development model was designed so that it could be a variation in the learning of puppets and optimize student movement by

PJKR

http://jurnal.unimed.ac.id/2012/index.php/jpehr 
utilizing existing facilities and infrastructure. Learning in the form of this game is competitive so that it can increase morale, fair play attitude and high fighting spirit.

\section{Discussion}

After making the initial product draft of the traditional game development model before it was finished, the product was tested on the fifth grade students of SD Negeri 98 North Bengkulu using a total sampling method.

This small-scale trial aimed to find out and identify various problems such as weaknesses, deficiencies, or the effectiveness of the product when used by students. Data obtained from this trial was used as a basis for product revision before it was used in large scale trials.

Based on the data of the questionnaire results filled out by the students, the percentage of answers obtained in accordance with the aspects assessed was $80 \%$. Based on the criteria which were determined, the traditional game development model of hadang with the plyometric method met the criteria very well so that it was used for students in fifth grade SD Negeri 98 North Bengkulu. The following table is the results of the questionnaire on a small scale trial.

In data analysis of small-scale trials results carried out obtained through the results of cognitive and psychomotor tests that conducted with the acquisition of a percentage of $20 \%$ ( 2 people) with a very good category, the percentage of $50 \%$ (5 people) with good categories, the percentage of $10 \%$ ( 1 people) with enough categories, and a percentage of $20 \%$ ( 2 people) with less categories. Based on predetermined criteria, the traditional game development products using Plyometric fulfilled Good criteria so that they can be used for fifth grade students of SD Negeri 98 North Bengkulu. The factor which made this model acceptable to the fifth grade students of SD Negeri 98 North Bengkulu was the assessment of the quality of traditional hadang game models using the plyometric method carried out on the psychomotor and cognitive aspects which met the criteria Very well.

Based on expert evaluation as well as small scale trials the next step was large scale trials. Large-scale trials aimed to determine the effectiveness of changes which was conducted in evaluating cognitive and psychomotor tests and small-scale trials whether traditional game development models using plyometric methods could be used. Large-scale trial data were collected using a questionnaire.

Based on large-scale trials obtained the data of students who understood and were able to practice hadang traditional sport correctly by $89 \%$. Based on predetermined criteria, the development model of Hadang traditional game by using the plyometric method met the criteria very well, so that it could be used for fifth grade SD Negeri 98 North Bengkulu. The following table is the percentage of students' questionnaires. In the large group trials, the percentage was $21 \%$ (6 people) with very good category, the percentage of $43 \%$ (12 people) with good 
category, the percentage of $25 \%$ ( 7 people) with enough categories, and the percentage of $11 \%$ ( 3 people) with the category less.

The results of the analysis of large-scale trial data was in the percentage of the appropriate choice of answers $90 \%$. Based on the criteria which were determined, the development model of hadang traditional game by using the plyometric method fulfilled the criteria very well, so that from a large scale trial this model could be used for Fifth Grade students of SD Negeri 98 North Bengkulu. The factors which made this model acceptable to fifth grade students at SD Negeri 98 North Bengkulu were that from all aspects tested $90 \%$ of students were able to demonstrate well. Both from understanding the rules of the game and the application of attitude in traditional game activities used plyometric methods which were appropriate to the level of growth and development.

\section{Conclusion}

Products for developing traditional game models using the plyometric method can be already practiced on the test subjects. It was based on the results of the analysis of cognitive tests and psychomotor tests of the results of small-scale trials of $80 \%$ and large-scale trials of $90 \%$ and fulfilled very good criteria.

If there are no problems, the development of the game using the plyometric method can be continued, but if there is a problem, the game development model can be adjusted and then work evaluation can be carried out to obtain the suitability of the traditional game development model with the conditions and situations in the field.

\section{References}

Agustin, 2013. Permainan tradisional. Bandung: CV. Alfabeta.

Boy Indrayana, 2017. Pengaruh Permainan Tradisional Terhadap Pengembangan Gerak Dasar Siswa SD Negeri 196/1V Kota Baru Kota Jambi. Journal Physical Education, Health and Recreation. Volume: 2, Edisi: 1: 28-38.

Chu D. A, 1992. Jumping into Plyometrics. Illinois: Human Kinetics.

Redcliffe J C and Farentinos, R. C, 1985. Plyometric Explosive Power Training. Znded. Champaign. Illions: Human Kinetics Published, Inc.

Sabaruddin Yunis Bangun, 2014. The Role of Recreational Sport Toward the Development of Sport Tourism in Indonesia in Increasing the Nations Quality of Life. Asian Social Science. Volume: 10, Edisi: 5: 98-104.

Suharsimi, Arikunto, 2010. Prosedur Penelitian. Jakarta: Rineka Cipta.

Sugiyono, 2010. Metode Penelitian Pendidikan. Bandung: CV. Alfabeta.

Sumardiyanto, 2010. Strategi Pembinaan Olahraga Tradisional Indonesia. Bandung: FPOK-UPI.

Wasis D. Dwiyogo, 2004. Konsep Penelitian dan Pengembangan. Malang: Pusat Kajian Kebijakan Olahraga LEMLID-UM. 